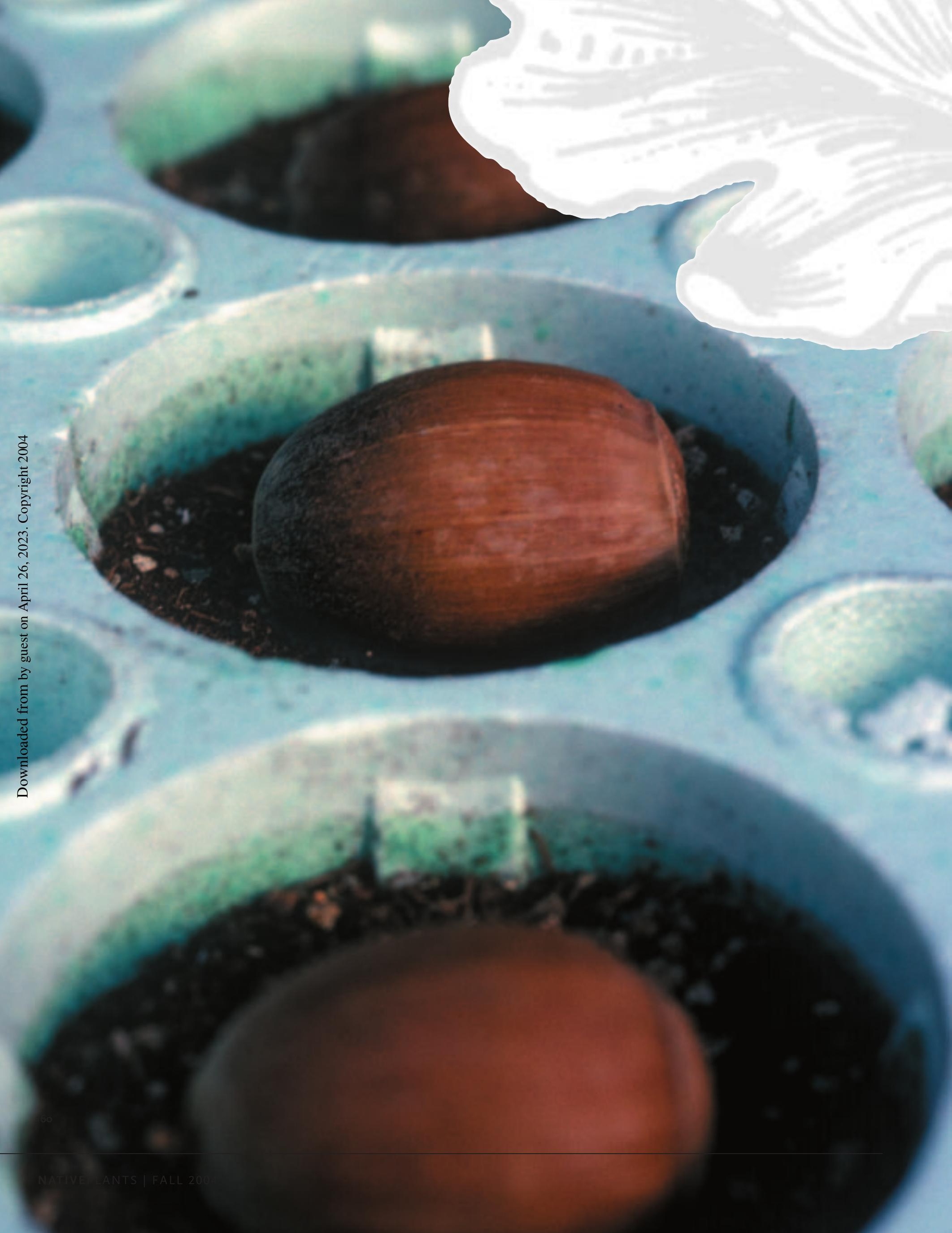




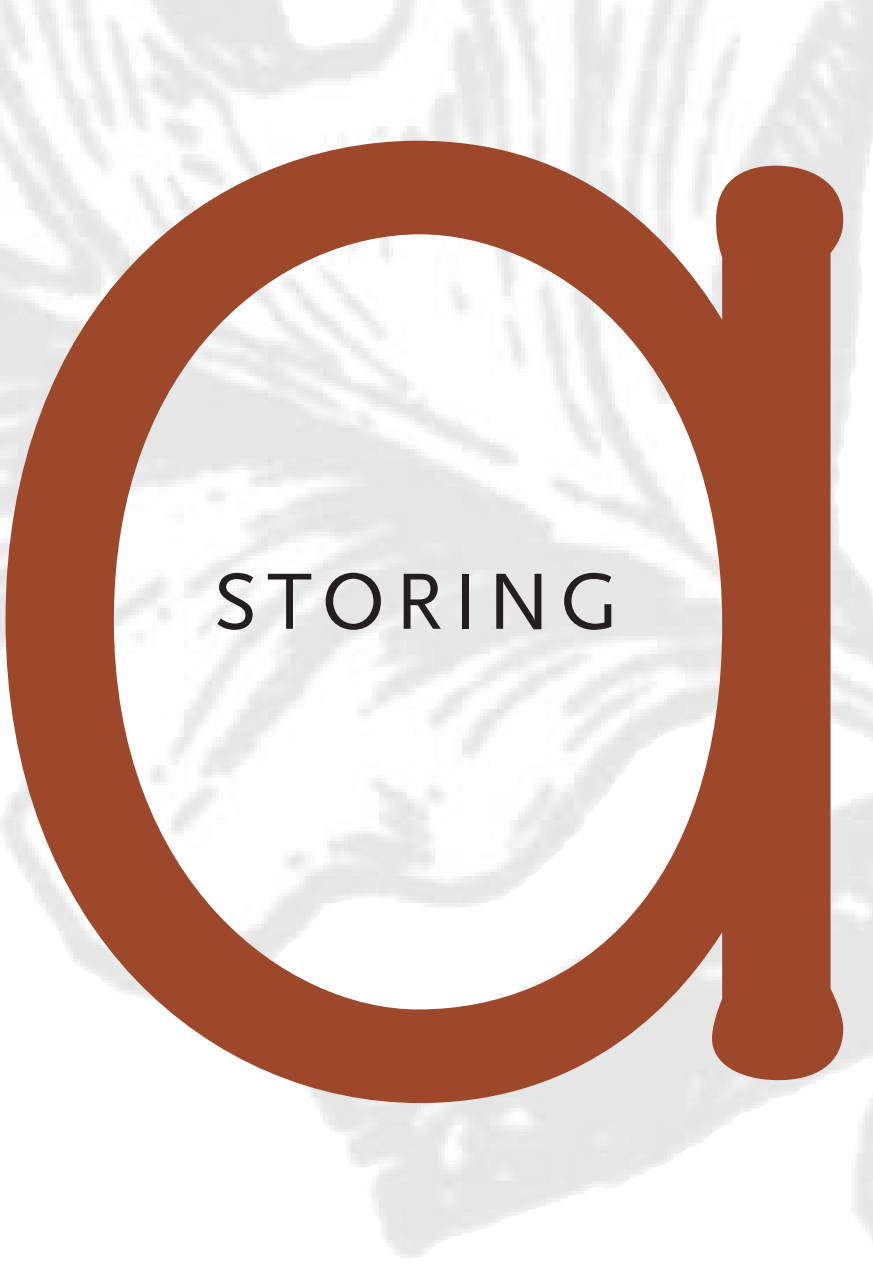

ABSTRACT

We examined changes that occurred in acorns during storage at different temperatures and moisture contents over a period of $3 \mathrm{y}$. In general, we found that to achieve optimum viability, acorns must be stored fully hydrated. Acorns also survived longer and sprouted less while in storage if stored at $-2{ }^{\circ} \mathrm{C}\left(28^{\circ} \mathrm{F}\right)$ instead of the usual $4{ }^{\circ} \mathrm{C}\left(39^{\circ} \mathrm{F}\right)$. However, we suspect damage to white oak embryonic axes at the lower temperature and at this time cannot recommend storage at $-2{ }^{\circ} \mathrm{C}$ for this species. While we were able to store fully hydrated red oaks for as long as $3 y$, we have been less successful with the white oaks. If you are in doubt about the quality of your acorns, go back to the basics-clip open a sample and check them for color and freshness.

KEY WORDS

oak, Quercus, moisture content, recalcitrant seeds, storage temperature

NOMENCLATURE USDA NRCS (2004)

Kristina Connor |

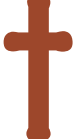

he oak genus, Quercus L. (Fagaceae), is the largest genus of hardwood trees and shrubs native to the US and includes both deciduous and evergreen species (Little 1979; Bonner 2002). Flowering is monoecious, and the nut produced from successful fertilization is commonly called an acorn. At the Center for Bottomland Hardwoods Research in Starkville, Mississippi, work on the seed problems of southern oaks has been in progress since 1967; my research on acorns began in 1991 and has concentrated on problems associated with long-term acorn storage. In the southern US, oaks are commercially important, valued both for their wood and for their benefits to wildlife, and are popular urban trees. An upsurge in hardwood nursery seedling production reflects this interest.

Most North American tree species have seeds that are "orthodox," meaning they can be dried to a moisture content $<12 \%$ and stored under refrigeration for many years (Roberts 1973). Oak acorns, however, are "recalcitrant," meaning they are sensitive to moisture loss and should not be dried before storage. This significantly lessens the time they can remain in storage without germinating or being overcome by fungi, mold, or insects (Bonner 1990). 


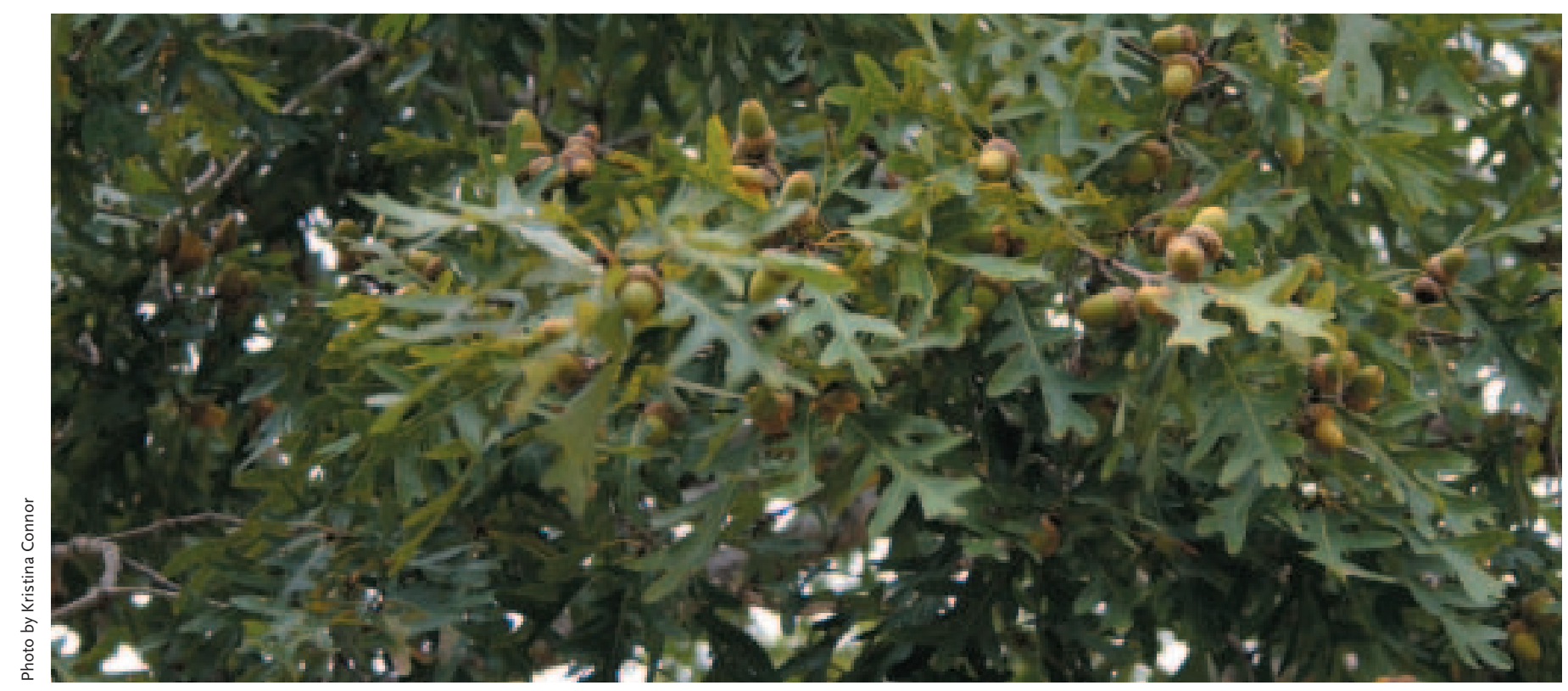

Figure 1. White oak leaves and acorns.

Additionally, the genus Quercus has 2 subgenera that have different seed storability regimes. The white oak subgenus, Lepidobalanus, has acorns that mature in 1 season and germinate soon after seed fall (Figure 1). These acorns are usually high in carbohydrates and cannot be stored for more than a few months. Acorns of the black and red oak subgenus, Erythrobalanus, usually take 2 y to mature, generally have a high lipid content, and may be stored for $>1 \mathrm{y}$ under ideal conditions (Connor and Bonner 1999; Connor and Sowa 2001, 2003; Sowa and Connor 2003; Connor 2004).

Because good acorn crops occur at irregular intervals and because most acorns cannot be stored for long periods of time and retain high vigor, hardwood

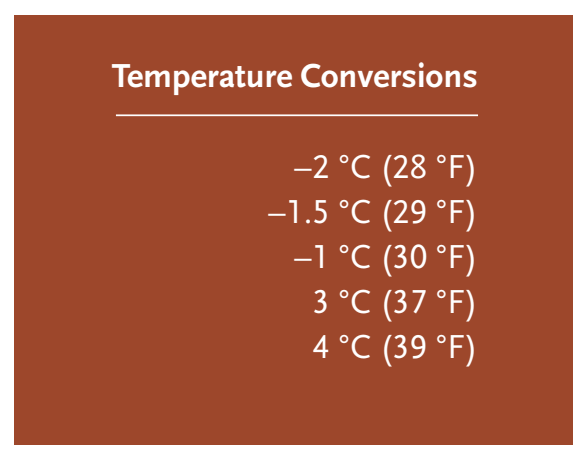

nursery managers have no backup supply of stored seeds; production of oak seedlings is literally at the mercy of nature.

\section{STORAGE EXPERIMENTS}

Dr Sharon Sowa and I have performed various experiments on many oak species, including 4 white oaks (Durand oak [Q. durandii Buckl.], live oak [Q. virginiana Mill.], swamp chestnut oak [Q. michauxii L.], and white oak [Q. alba L.]) and 2 red oaks (cherrybark oak [Q. pagoda Raf] and water oak [Q. nigra L.]). Also, with $\mathrm{Dr}$ Frank Bonner, work has been done on a white oak (chinkapin oak [Q. muehlenbergii Engelm.]) and 2 red oaks (northern red oak [Q. rubra L.] and Shumard oak [Q. shumardii Buckl.]). Our experiments are generally 1 of 2 types: 1 ) examining changes that occur during storage at different temperatures and acorn moisture contents over a period of up to $3 \mathrm{y}$; or 2) examining changes that occur when acorns are left at room temperature and allowed to dry over a period of up to $12 \mathrm{~d}$. In both types of experiments, we look for the simple change in acorn viability and/or for more complex biochemical changes in storage lipids, membrane

\section{TABLE 1}

Moisture content percentage of acorns before storage and germination percentage of fresh acorns.

\begin{tabular}{|c|c|c|c|}
\hline \multirow[t]{2}{*}{ Species } & \multicolumn{2}{|c|}{ Moisture content } & \multirow[t]{2}{*}{ Germination } \\
\hline & High & Low & \\
\hline Shumard oak & 33 & 25 & 99 \\
\hline Northern red oak & ak 46 & 35 & 99 \\
\hline Chinkapin oak & 40 & 31 & 91 \\
\hline
\end{tabular}

lipids, proteins, and carbohydrates of embryonic axis and cotyledon tissue. In the following sections, I describe some of the storage experiments and summarize our results. In all instances, moisture content was calculated on a fresh weight basis.

\section{EXPERIMENT 1 AND RESULTS -SHUMARD, CHINKAPIN, \\ AND NORTHERN RED OAKS}

We imposed high and low moisture levels for Shumard, chinkapin, and northern red oak acorns by either soaking in tap water for $16 \mathrm{~h}$ or by drying on a lab bench for $16 \mathrm{~h}$. We stored lots of 100 to 150 acorns in 4-mil polyethylene bags either in a refrigerator set at $3{ }^{\circ} \mathrm{C}$ or in a modi- 
Germination and sprouting percentages for chinkapin acorns stored for 1 ; northern red oak acorns stored for 1, 2, and 3 ; and Shumard acorns stored for 2 and $3 y$ at 2 different temperatures and 2 moisture content levels. ${ }^{a}$

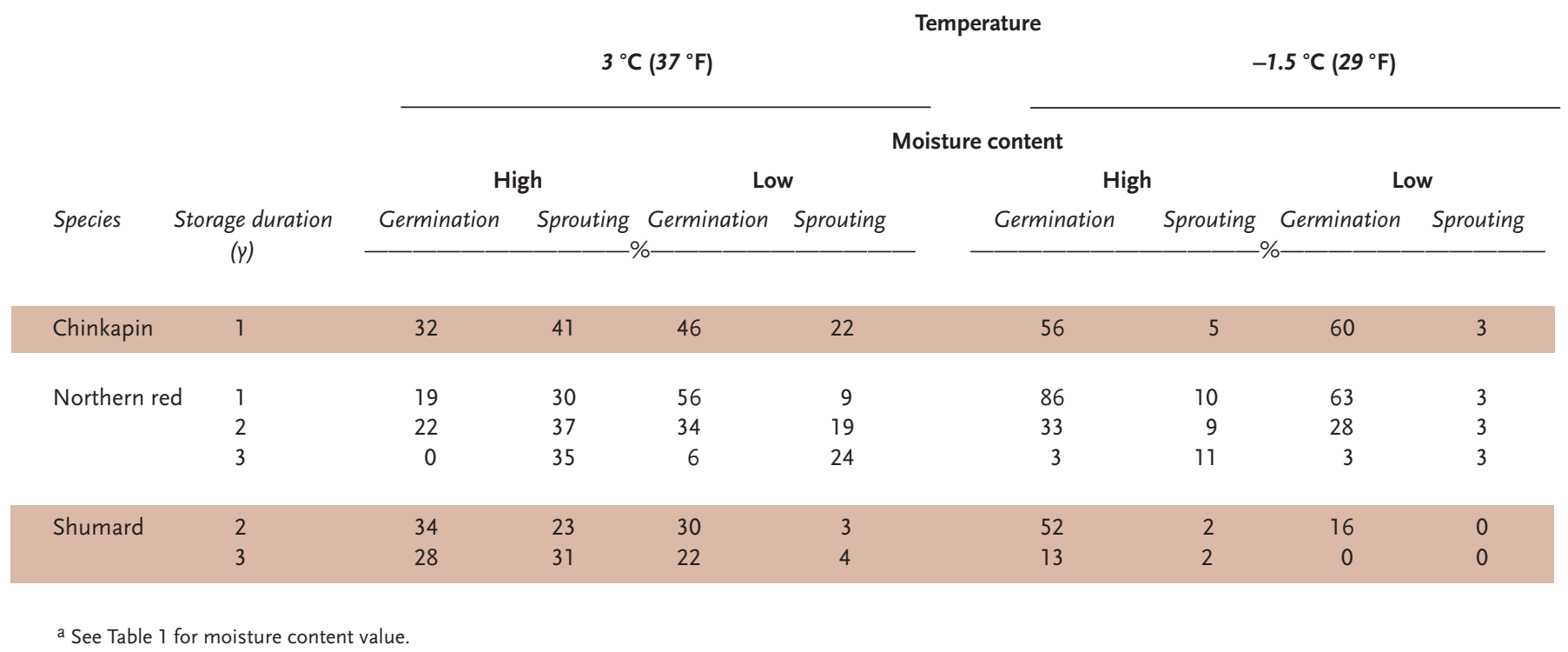

fied chest freezer set at $-1.5^{\circ} \mathrm{C}$. Temperature in the latter fluctuated from -1 to -3 ${ }^{\circ} \mathrm{C}$. We determined the original germination percentage for all species and tested them again as follows: after 1 and $2 y$ for chinkapin oak; after 1, 2, and 3 y for northern red oak; after 2 and $3 y$ for Shumard oak. Acorns were germinated as 6 replications per sampling period.

We found that high moisture contents ranged from 33\% (Shumard) to $46 \%$ (northern red) and low from 25\% (Shumard) to $35 \%$ (northern red); original viability averaged above $90 \%$ for all species (Table 1). Chinkapin oak did not survive for more than $1 \mathrm{y}$ in storage (Table 2); by $1 \mathrm{y}$, sprouting was prevalent, especially in the high temperature treatment $\left(3{ }^{\circ} \mathrm{C}\right)$, and germination had been reduced by at least $30 \%$ for all treatments. Storage at the low temperature treatment $\left(-1.5^{\circ} \mathrm{C}\right)$ yielded the best results; moisture content at this temperature did not have a significant effect on storability. Northern red oak also did not store well beyond $1 \mathrm{y}$ (Table 2). Storage at $-1.5^{\circ} \mathrm{C}$ kept germination high and sprouting at a minimum; however, unlike chinkapin oak, acorn moisture was a factor in stor- age. The acorns stored at $-1.5^{\circ} \mathrm{C}$ and high moisture content yielded significantly better germination results than those dried prior to storage. By the second year, however, germination had dropped below $35 \%$, even in the best storage treatment of $-1.5{ }^{\circ} \mathrm{C}$ high moisture content; and by year 3 , survival in all treatments was minimal. The best 2-y storage treatment for Shumard oak was also $-1.5^{\circ} \mathrm{C}$ high moisture content (Table 2). Like chinkapin oak, however, Shumard oak germination had fallen more than $30 \%$ from the original value, and by year 3 , viability had dropped to $<30 \%$ for all treatments.

\section{EXPERIMENT 2 AND RESULTS -WATER AND CHERRYBARK OAKS}

We imposed high and low moisture levels for water and cherrybark oak acorns by either soaking in tap water for $16 \mathrm{~h}$ or by drying on a lab bench for $48 \mathrm{~h}$. We stored lots consisting of 110 to 120 acorns in 4-mil polyethylene bags at either $4{ }^{\circ} \mathrm{C}$ in a Lab-Line Ambi-Hi-Low Chamber or at $-2{ }^{\circ} \mathrm{C}\left(28^{\circ} \mathrm{F}\right)$ in a modified chest freezer. We determined the original germination percentage and moisture contents for fresh acorns and thereafter at yearly intervals for $3 \mathrm{y}$. Acorns were germinated as 2 replications of 50 acorns per sampling period and were soaked overnight in tap water prior to germination testing.

Water oak acorn moisture content was $30 \%$ for the fresh acorns and $26 \%$ for those dried $2 \mathrm{~d}$ prior to storage. Drying reduced initial acorn viability by $9 \%$ (Figure 2). After $1 \mathrm{y}$, temperature of storage had a greater effect on seed viability than did initial moisture content. Both fully hydrated and dried acorns stored at $-2{ }^{\circ} \mathrm{C}$ maintained a higher viability than those stored at $4{ }^{\circ} \mathrm{C}$. This was not the case after $2 \mathrm{y}$ of storage, when moisture content became the more important factor. Acorns that had been dried prior to refrigeration had lower viability than those stored fully hydrated. Moisture content did not change significantly throughout the course of the experiment. Cherrybark oak acorn moisture content was 30\% for the fresh acorns and 20\% for those dried $2 \mathrm{~d}$ prior to storage. Drying reduced initial viability by only $2 \%$ (Figure 2). Unlike water oak acorns, moisture content, rather than temperature, was the 

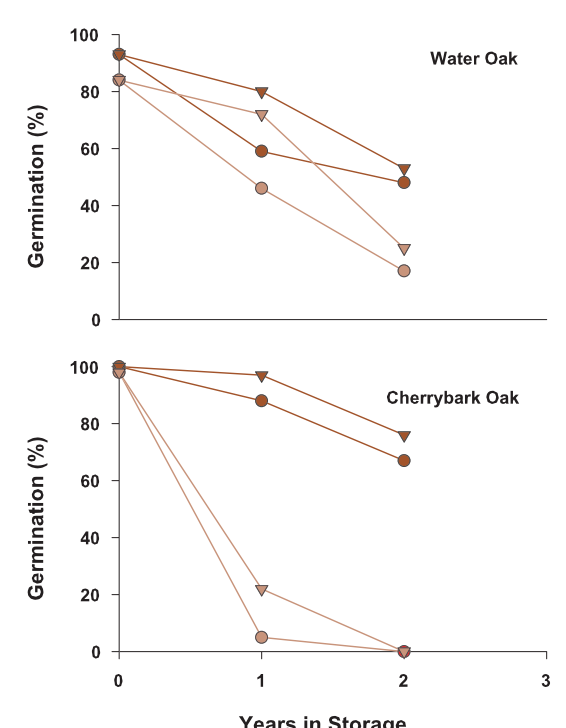

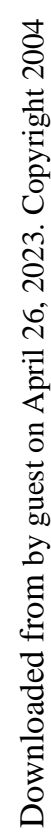

Figure 2. Germination of water oak and cherrybark oak acorns stored at 2 termperatures and 2 moisture contents for $3 y$.

important factor after both 1 and $2 y$ of storage. Only acorns stored in the fully hydrated condition retained high viability; dried acorns experienced significant losses in viability after only $1 \mathrm{y}$ in storage and were dead after $2 \mathrm{y}$. Changes in moisture content during storage were not significant.

\section{EXPERIMENT 3 AND RESULTS - SWAMP CHESTNUT, DURAND, LIVE, AND WHITE OAKS}

We stored swamp chestnut oak acorns from Texas either fully hydrated or dried on the lab bench for 3 or $6 \mathrm{~d}$ prior to storage. The large size and limited number of these acorns restricted the quantity stored to 20 per bag. Additionally, we stored locally collected acorns of white, Durand, and live oaks at the fresh moisture content only. Acorns were stored at $4{ }^{\circ} \mathrm{C}$ or $-2{ }^{\circ} \mathrm{C}$ as described above. We determined the original germination percentage and tested again at 30-d intervals until viabil-

TABLE 3

Germination percentage and moisture content levels for acorns of white, Durand, live, and swamp chestnut oaks; the swamp chestnut oak acorns were stored fresh and after dring 3 and $6 d$.

\begin{tabular}{llll} 
Species & Treatment & $\begin{array}{c}\text { Moisture content } \\
\text { (\%) }\end{array}$ & $\begin{array}{c}\text { Germination after treatment } \\
\text { (\%) }\end{array}$ \\
\hline Swamp chestnut & Fresh & 48 & 100 \\
& Day 3 & 46 & 100 \\
& Day 6 & 43 & 95 \\
White & Fresh & 52 & 96 \\
Durand & Fresh & 38 & 98 \\
Live & Fresh & 57 & 92 \\
& & & \\
\hline
\end{tabular}

Germination and sprouting percentage of white oak acorns stored for $120 \mathrm{~d}$ at 2 temperatures.

\begin{tabular}{|c|c|c|c|c|}
\hline \multirow[b]{3}{*}{ Days stored } & \multicolumn{4}{|c|}{ Temperature } \\
\hline & \multicolumn{2}{|c|}{$4^{\circ} \mathrm{C}\left(39^{\circ} \mathrm{F}\right)$} & \multicolumn{2}{|c|}{$-2^{\circ} \mathrm{C}\left(28^{\circ} \mathrm{F}\right)$} \\
\hline & Germination & Sprouting & Germination & Sprouting \\
\hline 0 & 93 & 0 & 93 & 0 \\
\hline 30 & 82 & 0 & 87 & 0 \\
\hline 60 & 48 & 31 & 51 & 0 \\
\hline 90 & 12 & 37 & 41 & 0 \\
\hline 120 & 17 & 53 & 30 & 0 \\
\hline
\end{tabular}

radicles had emerged (sprouted). We germinated acorns as 2 replications per sampling period; acorns were rehydrated overnight in tap water prior to germination testing.

The moisture contents of fresh acorns versus those dried for 2 to $6 \mathrm{~d}$ varied by as little as $5 \%$ for swamp chestnut oak (Table 3 ); original viability of treated seeds for this species averaged $80 \%$ or more. Swamp chestnut oak acorns stored poorly at $4{ }^{\circ} \mathrm{C}$. When stored at $-2{ }^{\circ} \mathrm{C}$ for $90 \mathrm{~d}$, however, sprouting was negligible and acorns survived at $>50 \%$ viability (Figure 3 ).

Although white oak acorns averaged $93 \%$ viability when fresh, almost $90 \%$ of the acorns stored $90 \mathrm{~d}$ at $4{ }^{\circ} \mathrm{C}$ had sprouted or decayed (Figure 4); those stored at $-2{ }^{\circ} \mathrm{C}$ lost more than $60 \%$ viabil- ity after $90 \mathrm{~d}$ but did not sprout during storage (Table 4; Figure 5). Fresh moisture content was 38\% for Durand oak acorns and $57 \%$ for live oak acorns. Durand oak acorns stored at $-2{ }^{\circ} \mathrm{C}$ had significantly higher viability than those stored at $4{ }^{\circ} \mathrm{C}$ in as little as $30 \mathrm{~d}$ (Figure 6). After $210 \mathrm{~d}$, acorns stored at $-2{ }^{\circ} \mathrm{C}$ averaged $83 \%$ viability, while of those stored at $4{ }^{\circ} \mathrm{C}$ only $6 \%$ survived. After $1 \mathrm{y}$, viability of acorns stored at $-2{ }^{\circ} \mathrm{C}$ and $4{ }^{\circ} \mathrm{C}$ had dropped to $13 \%$ and $0 \%$, respectively. Acorns of live oak were the only ones tested so far that survived longer when stored at $4{ }^{\circ} \mathrm{C}$ than at $-2{ }^{\circ} \mathrm{C}$. However, viability dropped rapidly at either storage temperature and acorns did not survive $1 \mathrm{y}$ in storage. 


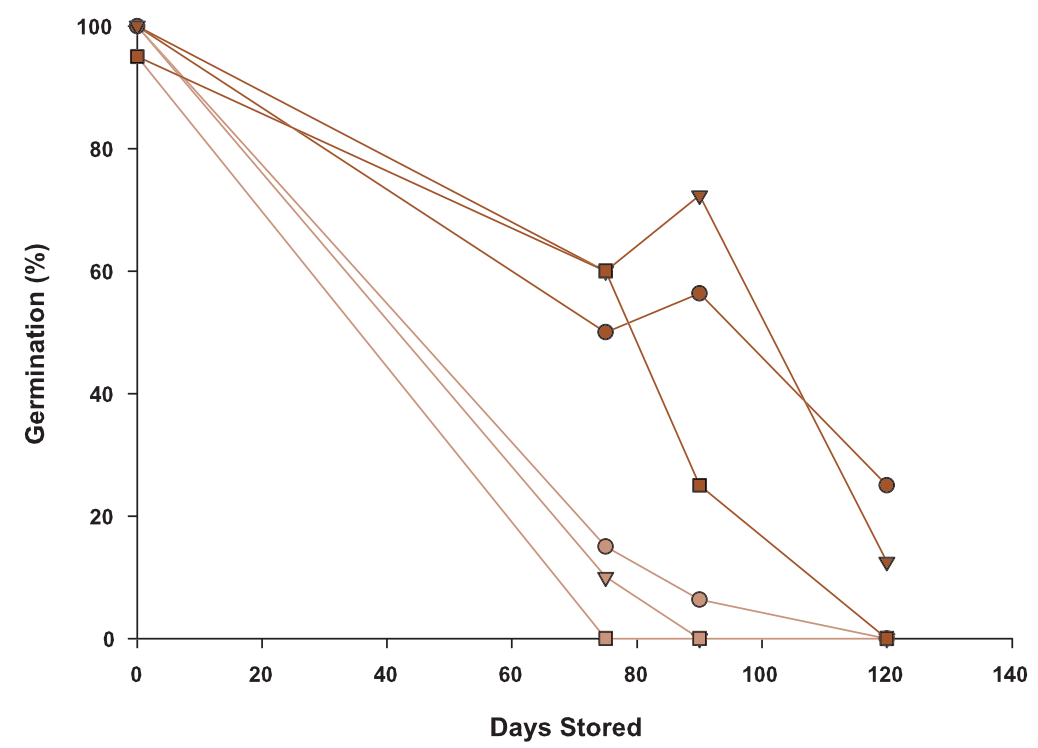

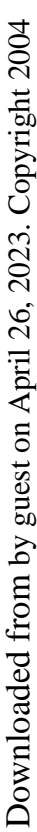

Figure 3. Germination of swamp chestnut oak acorns stored for up to $120 \mathrm{~d}$ at 2 temperatures and 3 moisture contents.

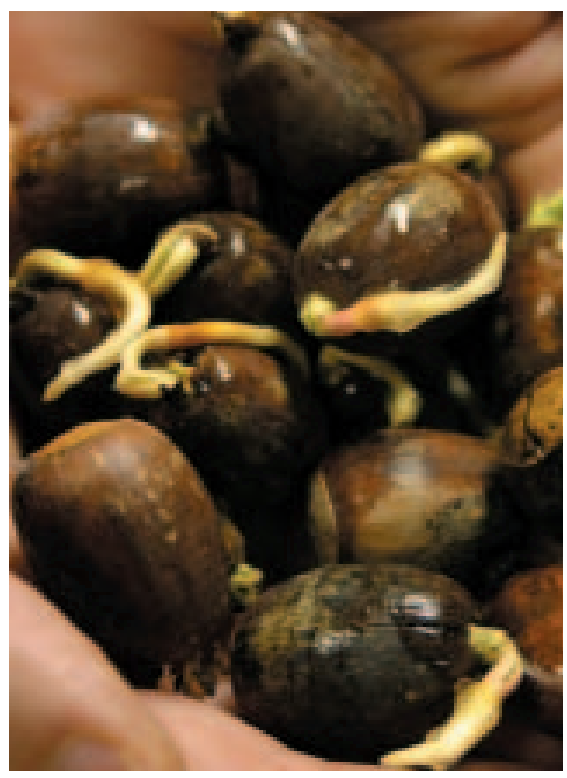

Figure 4. Nearly $90 \%$ of white oak acorns sprouted during $90 \mathrm{~d}$ of storage at $4{ }^{\circ} \mathrm{C}\left(29^{\circ} \mathrm{F}\right)$.

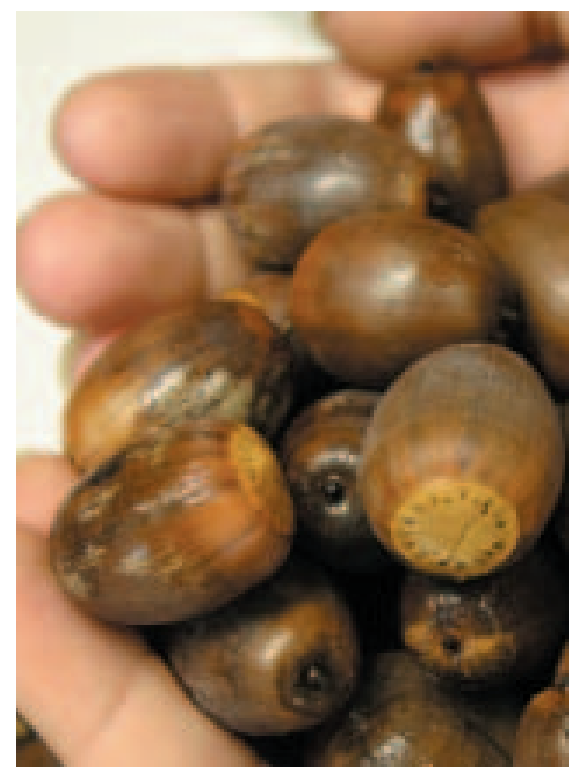

Figure 5. Storing white oak acorns at $-2{ }^{\circ} \mathrm{C}\left(28^{\circ} \mathrm{F}\right)$ $90 \mathrm{~d}$ prevented sprouting but more than $60 \%$ of the viability was lost.
While $-2{ }^{\circ} \mathrm{C}\left(28^{\circ} \mathrm{F}\right)$ storage shows promise for most acorns, suspected cold damage to live oak acorns and white oak embryonic axes leads us to state that no single temperature can be recommended for optimal acorn storage. We can conclude from these experiments, however, that it is best to collect and store acorns when they are fully hydrated. Generally, any moisture loss prior to storage resulted in a significant decrease in later viability; this was especially true of the cherrybark oak acorns stored for $1 \mathrm{y}$. If stored fully hydrated, germination was $88 \%$ or above while, if dried prior to storage, it was $22 \%$ or less.

Although we have had success extending storage of the red oaks, we have been less successful with the white oaks. The inability to store white oak acorns from one year to the next makes it impossible to solve acorn shortage problems if the crop fails. The best a seed company or nursery manager can do is make the most of what is available in good years.

Remember that when working with acorns, your goals are simple:

1. Collect acorns before they lose much water-this means collecting more than once or twice during acorn drop, especially in dry years.

2. Make sure acorns headed for storage are fully hydrated—soak overnight in tap water.

3. Separate bad acorns from good ones-skim off and discard the floaters after soaking.

4. Surface dry acorns-spread in a single layer and let surface dry before putting into cold storage; this should take $30 \mathrm{~min}$ or so and reduces mold growth during storage.

5. Store acorns under the best conditions possible-get acorns into cold storage as soon after collection as is feasible. 

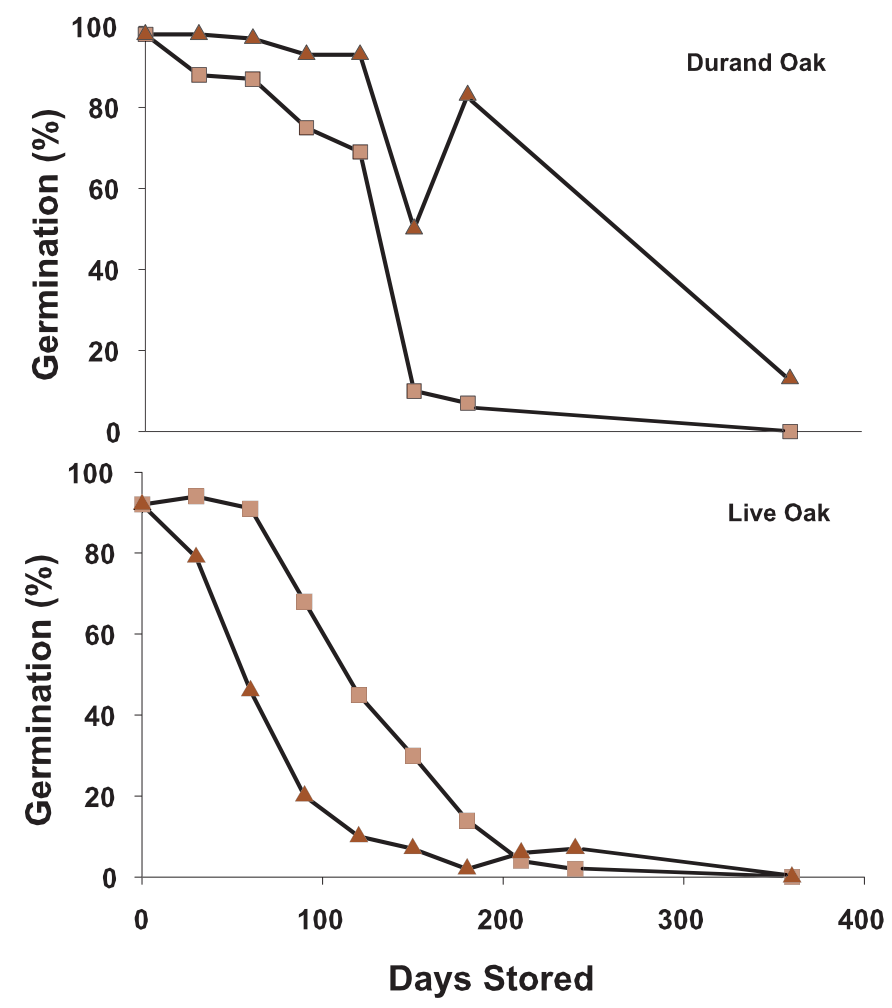

$\square$ Days stored at $4{ }^{\circ} \mathrm{C}\left(39^{\circ} \mathrm{F}\right)$

$\rightarrow$ Days stored at $-2^{\circ} \mathrm{C}\left(28^{\circ} \mathrm{F}\right)$

Figure 6. Germination of Durand and live oak acorns stored at 2 temperatures for up to a year.

Despite your best efforts, white oak acorns will germinate even under optimal cold storage conditions. The first sign of germination is a crack at the embryonic axis-end of the acorn followed by full extension of the radicle. Acorns can still be planted at this stage; the main radicle will probably die and laterals will branch from this. If left too long in storage, however, acorns degrade and germination decreases. Also, when white oak acorns are stored for a few months before planting, it is a good idea to check them for insect damage. The initial floating will not remove all damaged acorns, and weevils are active even under refrigeration. You may have a substantial number of damaged acorns, especially in a year with a poor acorn crop. When in doubt, use your nose and your clippers. A faint "alcohol" odor may indicate deteriora- have a yellowish discoloration, while healthy acorns have a smooth, creamycolored interior, with very wet, crisptextured cotyledons. Clipping open a sample of acorns to check color and quality is always a good idea.

\section{REFERENCES}

Bonner FT. 1990. Storage of seeds: potential and limitations for germplasm conservation. Forest Ecology and Management 35:35-43.

Bonner FT. 2002. Quercus L. Oak. Woody Plant Seed Manual. URL: http://www.wpsm.net (accessed 4 Feb 2004).

Connor KF. 2004. An update on oak seed quality research: hardwood recalcitrant seeds. National Proceedings, forestry and conservation nursery associations-2003. Ogden (UT): USDA Forest Service, Rocky Mountain Research Station. Proceedings RMRS-P-33. p 111-116.

Connor KF, Bonner FT. 1999. Effects of tempera-

\section{AUTHOR INFORMATION}

Kristina Connor

Plant Physiologist | Project Leader

USDA Forest Service

GW Andrews Forestry Sciences

Laboratory

530 Devall Drive

Auburn University, AL 36849

kconnor@fs.fed.us

ture and $M C$ on the storability of hardwood seeds. In: Haywood JD, editor. Proceedings, tenth biennial southern silvicultural research conference; 1999 Feb 16-18; Shreveport, LA. Asheville (NC): USDA Forest Service, Southern Research Station. General Technical Report SRS-30. p 123-126.

Connor KF, Sowa S. 2001. Recalcitrant behavior of temperate forest tree seeds: storage, biochemistry, and physiology. In: Outcalt KW, editor. Proceedings, eleventh biennial southern silvicultural research conference; 2001 Mar 20-22; Knoxville, TN. Asheville (NC): USDA Forest Service, Southern Research Station. General Technical Report SRS-48. p 47-50.

Connor KF, Sowa S. 2003. Effects of desiccation on the physiology and biochemistry of Quercus alba acorns. Tree Physiology 23:1147-1152.

Little EL, Jr. 1979. Checklist of United States trees (native and naturalized). Washington (DC): USDA Forest Service. Agricultural Handbook 541. 375 p.

Roberts EH. 1973. Predicting the storage life of seeds. Seed Science and Technology 1:499-514.

Sowa S, Connor KF. 2003. Recalcitrant behavior of cherrybark oak seed: an FT-IR study of desiccation sensitivity in Quercus pagoda Raf. acorns. Seed Technology 25(2):110-123.

USDA NRCS. 2004. The PLANTS database, version 3.5. URL: http://plants.usda.gov (accessed 12 Sep 2004). Baton Rouge (LA): National Plant Data Center. 